\title{
GIS における非標準雷インパルス波形の評価法
}

\author{
正 員 岡部 成光* 正 員 湯浅 禎之*
}

Evaluation Method of Non-Standard Lightning Impulse Waveforms for GIS

Shigemitsu Okabe*, Member, Sadayuki Yuasa*, Member

\begin{abstract}
For rationalizing equipment insulation level which can subsequently lead to reductions in the cost of substation equipment such as GIS's and transformers, it is necessary to reexamine insulating test voltages by investigating the method of evaluating lightning surge waveforms in terms of the equivalent standard lightning impulse waveforms. This paper describes the evaluation method for real surges (called non-standard lightning impulse waveform), based on insulation characteristics of gas gaps. The method is applied to typical surges in the lightning surge time region for various UHV and $500 \mathrm{kV}$ systems and it is obtained that the equivalent peak values of the standard lightning impulse waveform are possibly reduced by 20 to 30 percents.
\end{abstract}

キーワード：GIS，非標準雷インパルス波形 , 波形評価法

Keywords: GIS, non-standard lightning impulse waveform, evaluation method of waveform

\section{1. まえがき}

酸化亜鉛避雷器の高性能化，過電圧解析法の精緻化，機 器絶縁特性データの蓄積, 絶縁試験法の向上など最近の技 術的背景により，ガス絶縁開閉装置 (GIS) では絶縁合理 化, 試験電圧の低減が国際的にも進められている(1)。この 中で, 機器に加わるサージ過電圧, 特に雷サージ領域のサー ジ波形の評価が ,技術的課題の一つとして挙げられる ${ }^{(2)(3) 。}$ サージ波形に対する絶縁特性については, 面積則を用いた 検討がされているが(4)，実用的な絶縁評価手法については 未た課題となっている。従って,サージ波形 (以下,非標準 波形) を試験電圧波形である標準雷インパルス波形 (以下， 標準波形) へ等価的に換算評価することが重要である。非 標準波形は標準波形に比べ急峻ではあるものの，波形の減 衰が大きいために標準波形より絶縁的に厳しくないのが一 般的である。このため，非標準波形と標準波形を定量的に 比較評価することにより，絶縁仕樣の低減か期待できる ${ }^{(5)}$ 。

以上のような背景により，本研究では非標準波形の特徵 を分類して，GIS の構成要素であるガスギャップとスペー サ沿面における絶縁特性を取得してきた ${ }^{(6)} \sim(11)$ 。本論文で は, 乥れらの絶縁特性に基づき, 非標準波形を標準波形に 等価的に換算評価する手法を検討する。

\footnotetext{
東京電力 (株) 技術開発研究所

干 230-8510 横浜市鶴見区江ヶ崎町 4-1

Engineering R\&D Division, Tokyo Electric Power Company

4-1, Egasaki-cho, Tsurumi-ku, Yokohama 230-8510
}

\section{2. 非標準波形の分類}

GIS に発生する雷サージ領域の非標準波形について， EMTP (Electro-Magnetic Transients Program) ${ }^{(12)} に よ$ る解析結果を分析し, 以下のような特徵的な波形が抽出さ れた。

（1）波頭に突出した急峻部を有し，波尾部はフラット な波形で, 本論文では B 波形と称することにする。これは， 最初にパルス的な高い電圧が変電所に侵入し, 弚の後は避 雷器の保護レベルに落ち着く現象であり，普遍的に発生す る波形である。

（2）第 1 波がピークとなる減衰振動波形を $\mathrm{C}$ 波形とす る。これは, 変電所が直列/並列の共振点を有し, 特に入口 ブッシングと末端開放点との間の振動が支配的となること が考えられ，これも一般的な゙波形である。

(3) 第 1 波でなく第 2 波以降でピークとなって減衰振 動する波形を D 波形と称することにする。これは, ブッシ ングと変電所外部の送電線逆フラッシオーバ点との間の往 復反射による後追いの侵入サージなどの重畳などによるも ので, C 波形の派生形である。

(4) 低周波成分と高周波成分が重畳した減衰振動波形 を $\mathrm{E}$ 波形と称する。これは，変電所において，母線などの 比較的長い経路と分岐点区間などの短い経路でのサージの 往復反射が重畳したものであり，500 kV 系のような広がり の大きな変電所では一般的である。

(5) 非標準波形の基本要素となっている単発パルス波 形を $\mathrm{A}$ 波形として，別途に扱う。 B , C , D , E の波形を標 
準波と比較しての特徵は, 波頭部が急峻で振動的であると いうことである。この部分の特性を明確にするため，別途 扱うこととした。B 波形でフラット部が低い場合や $\mathrm{C}$ 波形

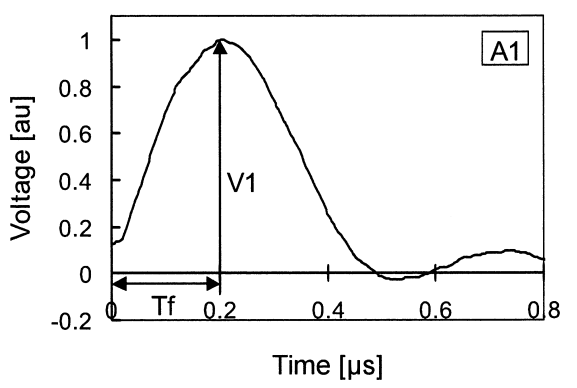

(a) Waveform A

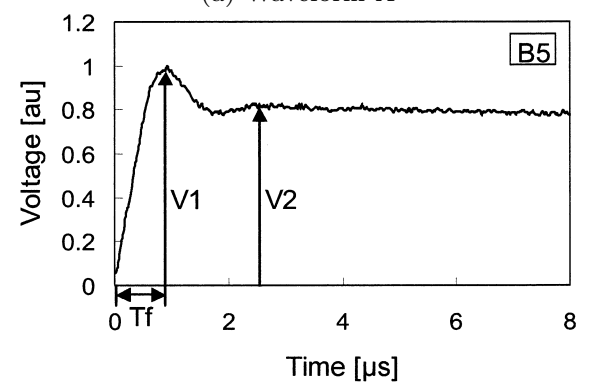

(b) Waveform B

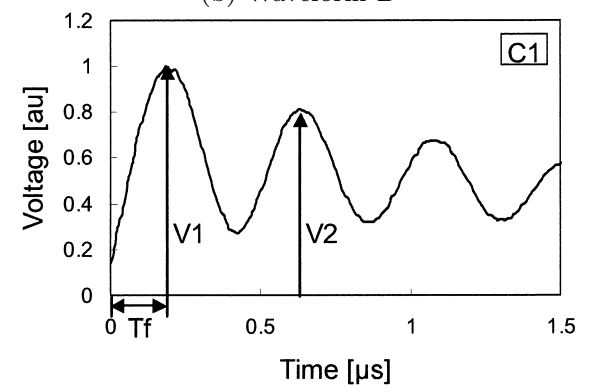

(c) Waveform $\mathrm{C}$

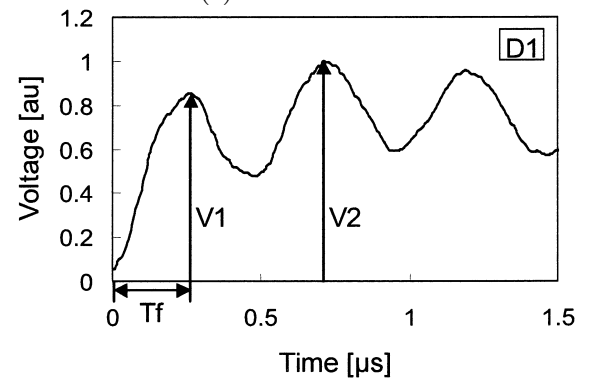

(d) Waveform D

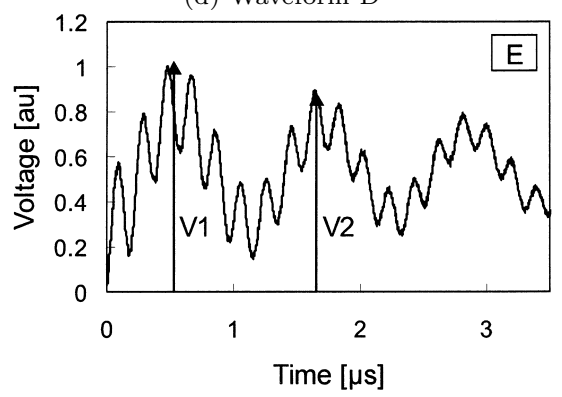

(e) Waveform E

図 1 非標準波形例

Fig. 1. Example of non-standard waveforms.
で第 2 波以降の減衰が大きい場合は, 直接当てはまるもの でもある。

以上より抽出した A , B , C , D , E の 5 種類の非標準波 形を一例ずつ，図 1 に示す。

\section{3. $\mathrm{SF}_{6}$ ガスギャップの基礎絶縁特性 ${ }^{(6) \sim(11)}$}

GIS の要素モデルとしては, ガスギャップと絶縁スペー サ沿面が考えられるが， これまでの検討における両者の絶 縁特性およひ設計電界の比較から，本論文の GIS の絶縁評 価ではガスギャップを対象とした ${ }^{(7)}$ 。

〈3. 1) $\mathbf{S F}_{6}$ ガスギャップモデル 图 2 に示す供試タ ンク内に , ステンレス製およびアルミ製半球棒一平板電極系 を配置した。電極表面は鏡面仕上げであり，電界利用率 $\eta$ は 0.45 および 0.60 である。スケール効果の検討も行った ため，表 1 に各スケールでのギャップ構成を示す。なお， ガス圧力は， $0.50 \mathrm{MPa}$ abs. $\left(20^{\circ} \mathrm{C}\right)$ である。

〈3. 2〉 試験波形 試験波形は, 上述の A, B , C , D ,

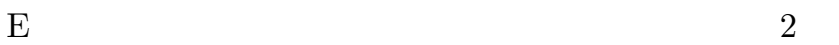
通りである。各波形の発生および試験方法などの詳細は， 既報を参照していただきたい( ${ }^{(6) \sim(10)}$ 。

〈3. 3〉 ガスギャップ絶縁特性のまとめ ${ }^{(6)}$ (11) 各波 形に対するガスギャップの絶縁特性を以下にまとめる。

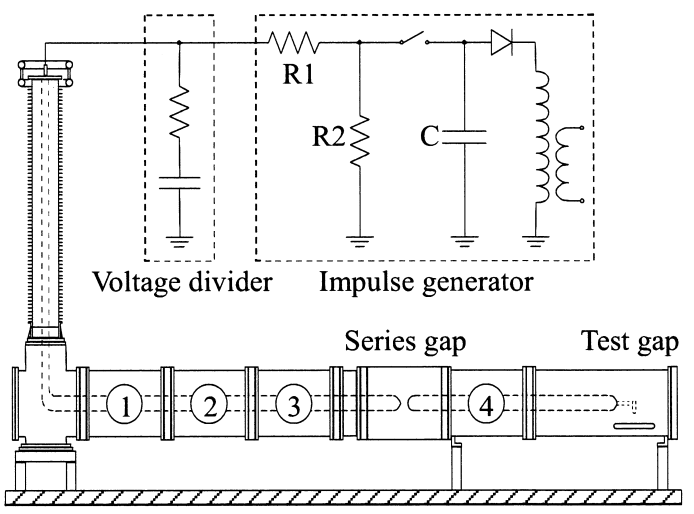

図 2 ガスギャップ試験時の供試タンク

Fig. 2. Tested tank for gas gap test.

表 1 ギャツプ条件

Table 1. Gap conditions.

\begin{tabular}{|c|c|c|c|c|}
\hline No. & Gap No. & $\begin{array}{c}\text { Diameter of rod } \\
\text { electrode }\end{array}$ & Gap length & $\eta$ \\
\hline 1 & G1 & $\phi 15 \mathrm{~mm}$ & $12 \mathrm{~mm}$ & 0.45 \\
\hline 2 & G2 & $\phi 20 \mathrm{~mm}$ & $9 \mathrm{~mm}$ & 0.60 \\
\hline 3 & G3 & $\phi 30 \mathrm{~mm}$ & $25 \mathrm{~mm}$ & 0.45 \\
\hline 4 & G4 & $\phi 40 \mathrm{~mm}$ & $19 \mathrm{~mm}$ & 0.60 \\
\hline 5 & G5 & $\phi 40 \mathrm{~mm}$ & $35 \mathrm{~mm}$ & 0.45 \\
\hline 6 & G6 & $\phi 56 \mathrm{~mm}$ & $27 \mathrm{~mm}$ & 0.60 \\
\hline 7 & G7 & $\phi 50 \mathrm{~mm}$ & $44 \mathrm{~mm}$ & 0.45 \\
\hline 8 & G8 & $\phi 70 \mathrm{~mm}$ & $33 \mathrm{~mm}$ & 0.60 \\
\hline
\end{tabular}


（1） A 波形，B 波形波頭部，C 波形，D 波形， E 波形

G1 ギャップにおける A 波形の V-t 特性 , G2 ギャップ における D 波形の V-t 特性および G2 ギャップにおける $\mathrm{E}$ 波形のV-t 特性の例を, 弚れ図 3 ,图 4 および図 5 に示 す。図中の Vmin は各波形に対する V-t 特性における波形 全体の最低破壞電圧であり，V1min およびV2min は光れ 第 1 波，第 2 波での最低破壊電圧を示している ${ }^{(6)}$ ( (8)。 また ,图 5 中の $\tau$ は, 振動減衰の目安としてピーク值の $1 / \mathrm{e}$ となる時間を示している ${ }^{(9)(10)}$ 。

$\mathrm{A}$ 波形 7 ケースおよび標準波形について，ピーク值の 80\%以上の電圧が継続している時間で整理すると，一つの 特性線で表わされる ${ }^{(7)}$ 。この $80 \%$ のレベルは, 各波形に対 する破壊時間の分布と統計処理の相関係数などから求めた ものである。なお，この閾值レベルの詳細は，既報を参照 していただきたい(7)(8)。

$\mathrm{B}$ 波形の波頭部は $\mathrm{A}$ 波形弚のものであり，C，D，E 波 形に関しては ,ピークの $80 \%$ 以上となる時間の総和で考え ると，A 波形の特性にほぼ一致した。即ち，A 波形，B 波

表 2 実験波形のパラメータ

Table 2. Parameters of experimental waveforms.

\begin{tabular}{|c|l|}
\hline Waveforms & \multicolumn{1}{|c|}{ Range of parameters } \\
\hline \multirow{2}{*}{ A } & Tf: $0.20 \sim 0.91 \mu \mathrm{s}$ \\
& Tt: $0.26 \sim 1.84 \mu \mathrm{s}$ \\
\hline \multirow{2}{*}{ B } & Tf: $0.26 \sim 0.98 \mu \mathrm{s}$ \\
& V2/V1: $0.70 \sim 0.90$ \\
\hline \multirow{2}{*}{ C } & Tf: $0.094 \sim 1.2 \mu \mathrm{s}$ \\
& V2/V1: $0.75 \sim 0.90$ \\
\hline \multirow{2}{*}{ D } & Tf: $0.25 \sim 0.94 \mu \mathrm{s}$ \\
& V2/V1: $1.0 \sim 1.20$ \\
\hline \multirow{2}{*}{ E } & Tf: $0.25 \sim 0.94 \mu \mathrm{s}$ \\
& V2/V1: $0.82 \sim 0.96$ \\
\hline \multirow{2}{*}{ SLI* } & Tf: $1.2 \mu \mathrm{s}$ \\
& Tt: $50 \mu \mathrm{s}$ \\
\hline
\end{tabular}

*SLI: Standard lightning impulse waveform

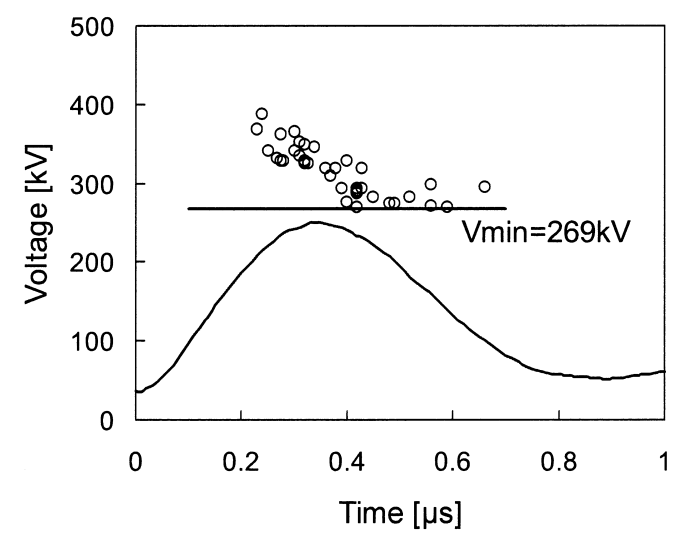

図 3 G1 ギャップにおける A 波形に対する $\mathrm{V}-\mathrm{t}$ 特性

Fig. 3. V-t characteristics for G1 gap under waveform $\mathrm{A}$.
形波頭部，C 波形，D 波形，E 波形については，図 6 に示 すように一つの特性で表される。図 6 の縦軸は, 各波形の Vmin を標準波形での Vmin (LIVmin) の比で表したもの

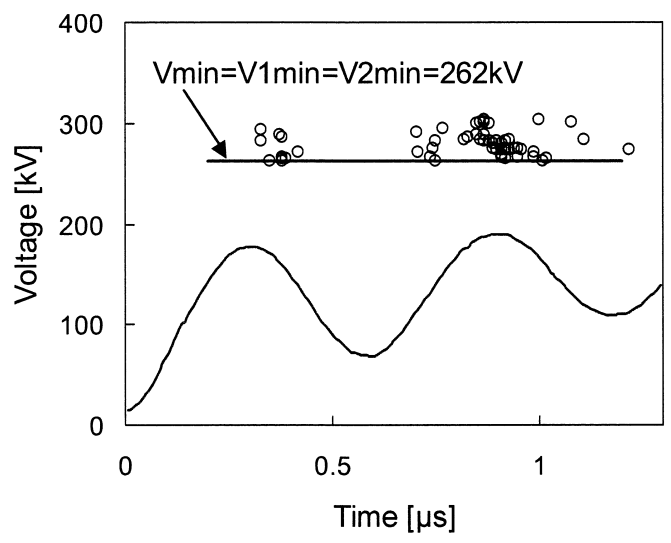

図 4 G2 ギャップにおける D 波形に対する $\mathrm{V}-\mathrm{t}$ 特性

Fig. 4. V-t characteristics for G2 gap under waveform $\mathrm{D}$.

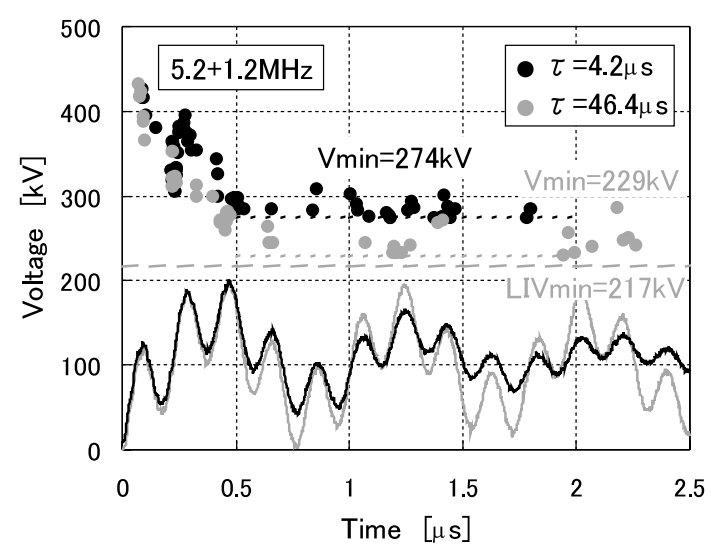

図 5 G2 ギャップにおける E 波形に対する $\mathrm{V}-\mathrm{t}$ 特性

Fig. 5. V-t characteristics for G2 gap under waveform $\mathrm{E}$.

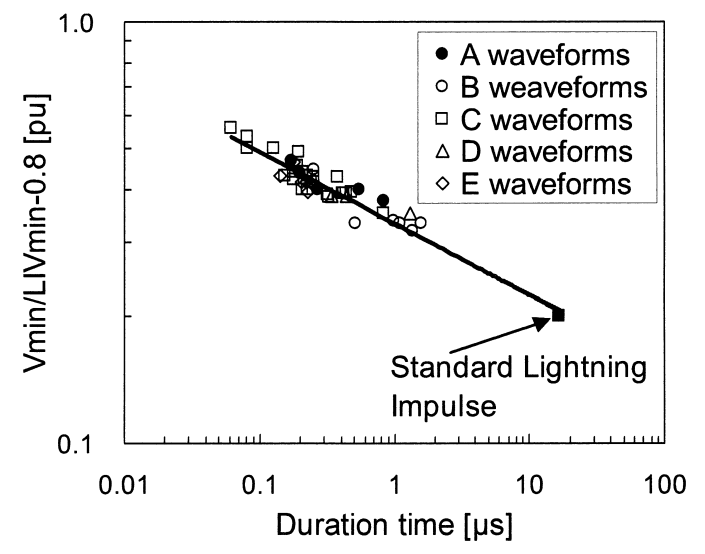

図 6 継続時間で整理した $\eta=0.60$ ギャップの特性

Fig. 6. Characteristics for $\eta=0.60$ gaps arranged according to duration time. 


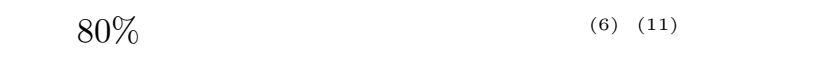
図にはステンレス製およびアルミ製電極における特性を共 に記してあり，両者の特性についても標準波形に対する比 で見ると一致する結果となった。

（2） B 波形後続フラット部Ｂ 波形の後続フラット 部では，最低破壊のフラット部電圧が標準波破壊電圧の $90 \%$ 程度であった。また標準波の破壊の時間遅れは最大約 $8 \mu \mathrm{s}$ であり，光の瞬時電圧はピークの約 $90 \%$ であることか ら，B 波形の後続フラット部は，0.90で除すことにより 標 準波形へ換算可能であると考えられる。

4. 非標準波形評価法のアルゴリズム

3 章の各種非標準波形に対する各種ガスギャップの基礎
絶縁特性の整理結果に基づき, 非標準波形の評価法を検討 する。

基本的な考え方は次の通りである。

・最初に非標準波形を振動部分, フラット部分などに分 解する。

・各波形要素を等価的な標準波形のピーク值に換算する 係数を求める。

- 各波形要素の標準波形換算値のうち, 最大值が支配的 であると考えられるため, 光の最大值を波形全体の等 価的な標準波形換算值とする。

以上のアルゴリズムをフロー図にして , 図 7 に示す。

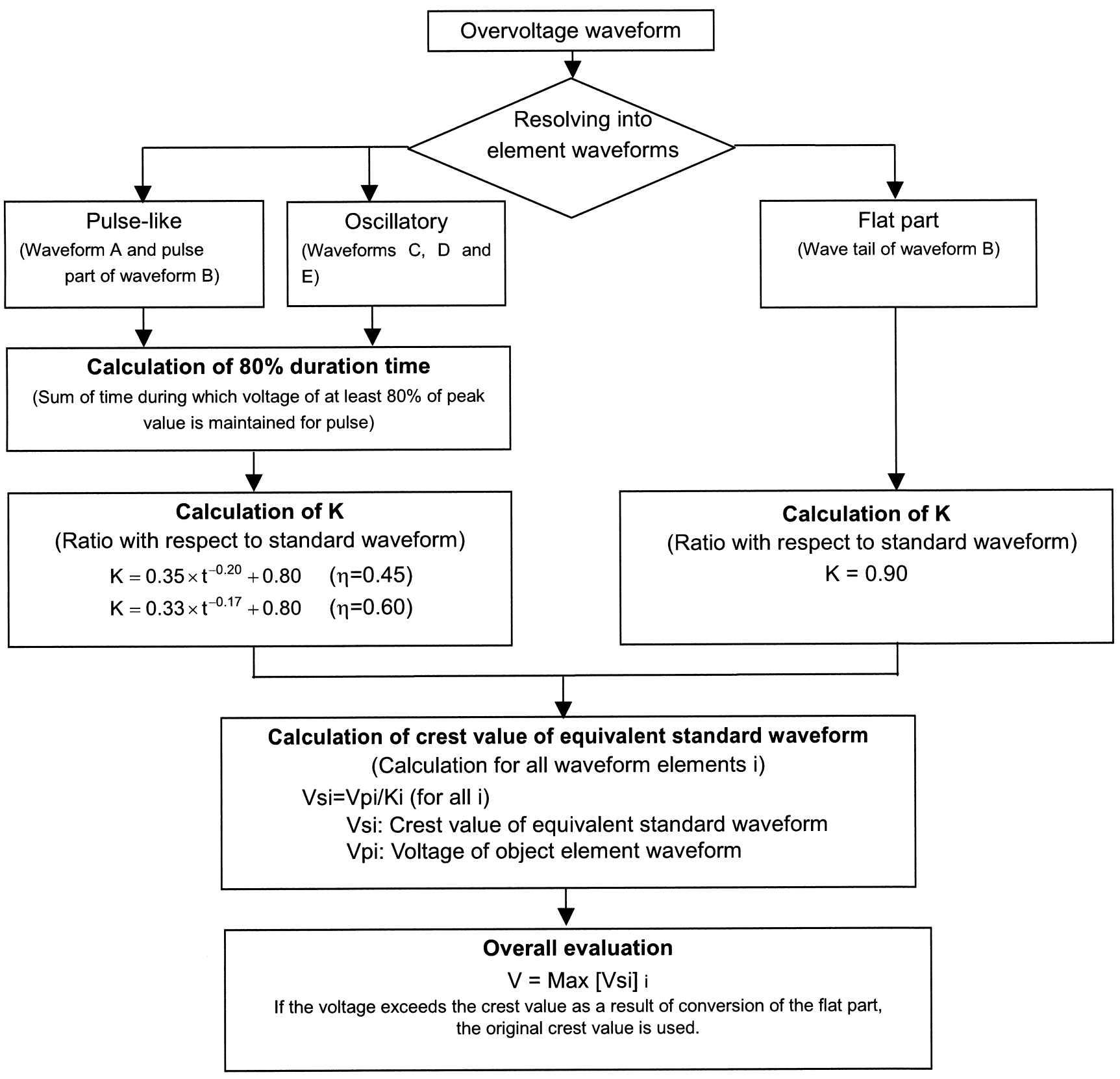

図 7 非標準波形評価法のアルゴリズム

Fig. 7. Algorithm for evaluation of non-standard waveform. 


\section{5. 評価法の適用例}

4 章で検討した非標準波形評価法を, UHV 変電所におけ る雷サージと $500 \mathrm{kV}$ ケーブル系変電所における断路器再 発弧サージの各一例に適用し，等価的な標準波形波高值を 求める。

〈5 1〉UHV 変電所雷サージ波形への適用图 8 は, $\mathrm{UHV}$ 架空変電所 ${ }^{(13)}$ における雷サージ解析波形である。こ の波形は，波頭にパルス部を有し，後続に避雷器保護レベ ルでフラットな形状となっており，いわゆる B 波形の形状 である。

図 7 のフローに従った評価を表 3 に示す。同表より，波 頭部の換算值の方が厳しく，波形全体としては，波高值が $2617 \mathrm{kV}$ から $2093 \mathrm{kV}$ へ 0.80 倍 (=1/1.25 倍) となった。

〈5. 2〉再発弧サージ波形への適用图 9 は, $500 \mathrm{kV}$ ケーブル系変電所での再発弧サージ解析波形である。この 波形は，低周波成分約 $1 \mathrm{MHz}$ ，高周波成分約 $5 \mathrm{MHz}$ の二 重周波振動波となっており， $\mathrm{E}$ 波形に相当する。

表 4 は, 図 7 のフローに沿った評価結果である。同表に おいて，換算值は $1165 \mathrm{kV}$ であり，ピーク值 $1401 \mathrm{kV}$ の 0.83 倍 (=1/1.20 倍) となった。

〈5.3〉考 察 本論文での評価で対象とした波形で は，ケース 1 が波頭部て絶縁レベルが決まり，ケース 2 で は低周波成分で見た第 1 波分て絶縁レベルが決まる結果と なった。

架空引き込み式の GIS 変電所においては, 通常引き込み 口に避雷器か設置してある。遮断器開放状態で外部から雷 サージが侵入し，一旦避雷器を通過後，遮断器開放端から 反射して来たサージが再び避雷器に差しかかり, 避雷器制 限電圧に抑えられるために , ケース 1 は変圧器などと比べ 波頭部と後続フラット部の電圧差が大きくなっている。こ の場合，評価フローにおいて波頭部が支配的であり，実験 的にも検証している ${ }^{(8)}$ 。

一方, 変電所内部で発生する断路器サージなどの再発弧 サージについては，ケース 2 のように振動成分が支配的と なっている。この場合は，C，D，E 波形の評価フローに 従って絶縁レベルが決定される。

$500 \mathrm{kV}$ 以上の GIS を主に対象とした他のケースにおい ても図 7 の評価フローを適用し，いずれも $20 〜 30 \%$ 程度の 低減となった。この結果は, サージ波形を定量的かつ低め に評価でき，GIS の雷インパルス試験電圧 (LIWV) の低 減，更には機器コスト低減の可能性を示唆するものである。

なお，本論文の評価法は，各実験波形 $(\mathrm{A}, \mathrm{B}, \mathrm{C}, \mathrm{D}, \mathrm{E}$ 波形) に対する絶縁特性データに基づいて構築した。従つ て, 評価の際分解した波形要素間の関係 (影響) や物理的 メカニズムについて，定量的には立脚していない実験式と も言える。また，実際のサージ波形の評価では，図 7 のフ ローにおいて，検討者の判断が必要な場合がある。これら に対する検討は今後の課題である。

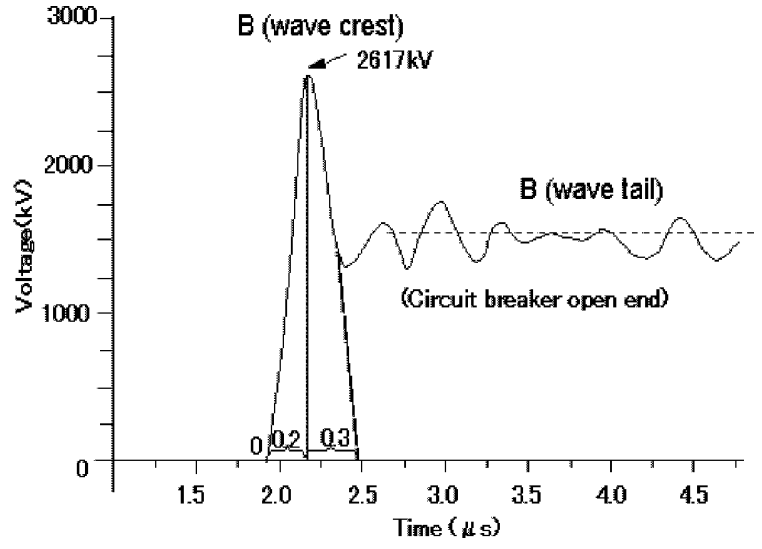

図 8 雷サージ波形の評価 (ケース 1 )

Fig. 8. Evaluation of lightning surge waveform (Case1).

表 3 雷サージ波形の評価 (ケース 1)

Table 3. Evaluation of lightning surge waveform in the GIS of a UHV system (Case1).

\begin{tabular}{|c|c|c|c|c|}
\hline $\begin{array}{c}\text { Waveform } \\
\text { element }\end{array}$ & $\begin{array}{c}80 \% \text { dura- } \\
\text { tion time }\end{array}$ & $\begin{array}{c}\text { Peak } \\
\text { voltage }\end{array}$ & $\begin{array}{c}\text { Conver- } \\
\text { sion ratio }\end{array}$ & $\begin{array}{c}\text { Equivalent SLI } \\
\text { voltage }\end{array}$ \\
\hline $\begin{array}{c}\text { B (wave } \\
\text { crest) }\end{array}$ & $0.16 \mu \mathrm{s}$ & $2617 \mathrm{kV}$ & $\begin{array}{c}1.25 \\
(1.30)\end{array}$ & $\begin{array}{c}2093 \mathrm{kV}[\eta=0.60] \\
(2005 \mathrm{kV}[\eta=0.45])\end{array}$ \\
\hline $\begin{array}{c}\text { B (wave } \\
\text { tail) }\end{array}$ & - & $\begin{array}{c}1517 \mathrm{kV} \\
(1760 \mathrm{kV})^{*}\end{array}$ & 0.90 & $\begin{array}{c}1686 \mathrm{kV} \\
(1956 \mathrm{kV})^{*}\end{array}$ \\
\hline
\end{tabular}

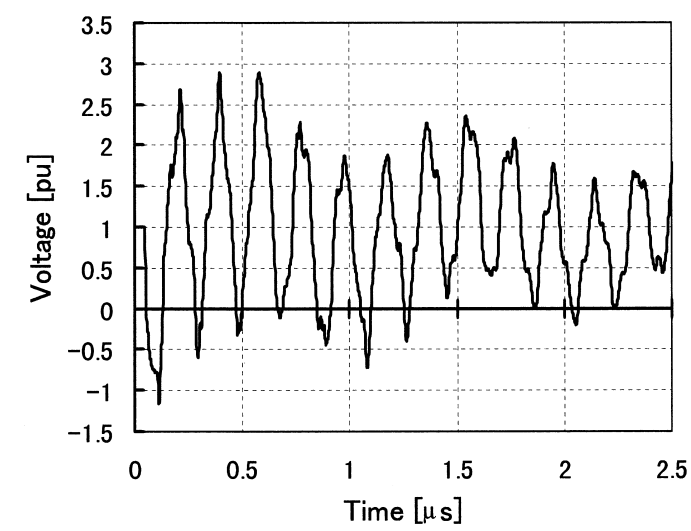

図 9 再発弧サージ解析波形の評価（ケース 2 )

Fig. 9. Evaluation of re-striking surge waveform (Case2).

表 4 再発弧サージ波形の評価（ケース 2)

Table 4. Evaluation of re-striking surge waveform in the GIS of a $500 \mathrm{kV}$ system (Case2).

\begin{tabular}{|c|c|c|c|c|}
\hline $\begin{array}{c}\text { Waveform } \\
\text { element }\end{array}$ & $\begin{array}{c}80 \% \text { dura- } \\
\text { tion time }\end{array}$ & $\begin{array}{c}\text { Peak } \\
\text { voltage }\end{array}$ & $\begin{array}{c}\text { Conver- } \\
\text { sion ratio }\end{array}$ & $\begin{array}{c}\text { Equivalent SLI } \\
\text { voltage }\end{array}$ \\
\hline $\begin{array}{c}\text { Oscillatory } \\
\text { part }\end{array}$ & $0.31 \mu \mathrm{s}$ & $1401 \mathrm{kV}$ & $\begin{array}{c}1.20 \\
(1.24)\end{array}$ & $\begin{array}{c}1165 \mathrm{kV}[\eta=0.60] \\
(1128 \mathrm{kV}[\eta=0.45])\end{array}$ \\
\hline
\end{tabular}




\section{6. まとめ}

本論文では，GIS の絶縁合理化を目的として，機器に加 わる雷サージ領域のサージ波形 (非標準波形) を機器試験 電圧波形である標準雷インパルス波形 (標準波形) へ換算 する評価法を検討した。弚の結果，下記項目が得られた。

(1) GIS の絶縁要素として,ガスギャップと絶縁スペー サ沿面を考えたが, 絶縁特性およひ設計電界值の比較から ガスギャップを対象とした。非標準波形として，A，B，C， $\mathrm{D}, \mathrm{E}$ 波形の 5 種類を想定し，実験で取得した絶縁特性か ら各波形を統一的に扱うことが可能となった。

（2）前項の結果を基に，非標準波形の評価法を検討し た。この評価法は,まず非標準波形を波形要素に分解し，次 に等価的な標準波形の波高值に換算し，各換算値の中から 最大値を波形全体の等価換算値とするものである。

（3）上記評価法を雷サージ波形と再発弧サージ波形の 各一例に適用し，等価的な標準波形波高值を検討した。今

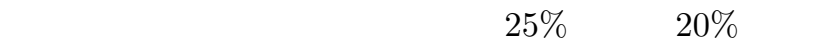
れた。

（4）雷サージ領域の非標準波形は，一般に標準波形よ り減衰が大きいため, 絶縁的に厳しくない場合が多く，光 の換算値は低減される。本評価法のように，非標準波形を 定量的に評価することにより，絶縁仕樣低減の可能性が得 られることを示唆した。

今後は，更に多くのケースに適用しながら，今回提案し た評価法の精緻化，改良などを行っていく予定である。 (平成 15 年 3 月 19 日受付, 平成 15 年 7 月 14 日再受付)

\section{文献}

(1) W. Schmidt and R. Malewski: Special Report for Group 33: CIGRE Session-2000, No.33-00 (2000-8)

（2）電気協同研究会：「絶縁設計の合理化」, 電気協同研究, Vol.44, No.3 (1988)

(3) 試験電圧の合理化協同研究委員会:「試験電圧と機器に関する諸特 性」, 電気学会技術報告, No.518 (1994-11)

(4) T. Yoshida, H. Fujinami, and T. Kawamoto: "V-t Characteristics of $\mathrm{SF}_{6}$ Gas for Lightning Surges", T. IEE Japan, Vol.116-B, No.10, pp.1232-1239 (1996-10) (in Japanese) 吉田智明・藤波秀雄・河本 正 : $\left\ulcorner\mathrm{SF}_{6}\right.$ ガスの雷サージに対する $\mathrm{V}-\mathrm{t}$ 特性の検討」, 電学論 B, 116, 10, pp.1232-1239 (1996-10)

(5) S. Okabe and M. Koto: "Evaluation of Non-standard Lightning Surge Waveforms in GIS", $10^{\text {th }}$ ISH, No.3117 (1997)

(6) S. Okabe, M. Koutou, S. Yuasa, T. Suzuki, T. Rokunohe, and T. Yamagiwa: "Analysis of Non-Standard Lightning Impulse Voltage for Actual Substation and Generation Circuit," IEEJ Trans. PE, Vol.123, No.2, pp.175-180 (2003-2) (in Japanese) 岡部成光 ·向當政典 · 湯浅禎之 ·鈴木俊之 · 六戶敏昭 - 山極時生 : 「実変電所に侵入する非標準雷インパルス波形の分析と発生回路」, 電学論 B, 123, 2, pp.175-180 (2003-2)

(7) S. Yuasa and S. Okabe: "Breakdown Characteristics in $\mathrm{SF}_{6}$ Gas under Non-Standard Lightning Impulse VoltageInsulation Characteristics for Gas Gap and Spacer Surface under Single Pulse Waveforms-", IEEJ Trans. PE, Vol.123, No.10, pp.1242-1249 (2003-10) (in Japanese)
湯浅禎之・岡部成光：「非標準雷インパルス波形に対する $\mathrm{SF}_{6}$ ガ ス中の絶縁破壊特性一単発パルス波形に対するガスギャップおよび スペーサ沿面の絶縁特性一」, 電学論 B , 123，10, pp.1242-1249 (2003-10)

(8) S. Yuasa and S. Okabe: "Breakdown Characteristics in $\mathrm{SF}_{6}$ Gas under Non-Standard Lightning Impulse VoltageInsulation Characteristics for Gas Gap under Oscillatory Waveforms-", IEEJ Trans. PE, Vol.123, No.10, pp.12501258 (2003-10) (in Japanese)

湯浅禎之・岡部成光:「非標準雷インパルス波形に対する $\mathrm{SF}_{6}$ ガス 中の絶縁破壞特性一振動成分を含む波形に対するガスギャップの絶 縁特性—」, 電学論 B, 123, No.10, pp.1250-1258 (2003-10)

(9) S. Yuasa, H. Suzuki, and S. Okabe: "Insulation Characteristics of GIS under Non-Standard Lightning Impulse Oscillations-Insulation Characteristics under SingleFrequency Oscillations with Various Frequencies and Damping Ratios-", T. IEE Japan, Vol.122-B, No.5, pp.652-658 (2002-5) (in Japanese)

湯浅禎之・鈴木浩文・岡部成光：「GIS の非標準雷インパルス振動 波形に対する絶縁特性一周波数と減衰を变えた単一周波振動波に対 する絶縁特性一」, 電学論 B, 122, 5, pp.652-658 (2002-5)

(10) S. Yuasa, H. Suzuki, and S. Okabe: "Insulation Characteristics of GIS under Non-Standard Lightning Impulse Oscillations-Insulation Characteristics under DoubleFrequency Oscillations with Various Frequencies and Damping Ratios-", T. IEE Japan, Vol.122-B, No.11, pp.1208-1214 (2002-11) (in Japanese)

湯浅禎之・加藤敬一・岡部成光：「GIS の非標準雷インパルス振動 波形に対する絶縁特性一周波数と減衰を変えた二重周波振動波に対 する絶縁特性一」, 電学論 B , 122, 11, pp.1208-1214 (2002-11)

(11) S. Yuasa and S. Okabe: "Insulation Characteristics of GIS under Non-Standard Lightning Impulse OscillationsEvaluation of Field Overvoltage Waveforms and Its Applications-", IEEJ Trans. PE, Vol.123-B, No.2, pp.223229 (2003-2) (in Japanese)

湯浅禎之・岡部成光：「GIS の非標準雷インパルス振動波形に対する 絶縁特性一フィールド過電圧波形評価法と年の適用一」, 電学論 B, 123, 2, pp.223-229 (2003-2)

(12) 日本 EMTP 委員会: Alternative Transient Program Rule Book (1994)

(13) T. Watanabe, Y. Yamagata, and E. Zaima: "Insulation Coordination for UHV System", CIGRE, 33-101 (1998)

岡 部 成 光 (正員) 1986 年 3 月東京大学大学院工学研究科

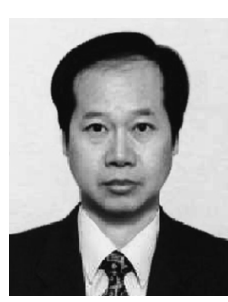
電気工学専攻博士課程修了。同 4 月，東京電力 (株) 入社。1992 年ミュンヘン工科大学客員研究 員。現在，技術開発研究所絶縁技術グループ。工 学博士。IEEE 会員。

湯 浅 禎 之 (正員) 1996 年 3 月名古屋大学大学院工学研究

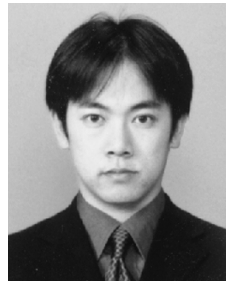
科電気工学専攻修士課程修了。同 4 月, 東京電力 (株) 入社。現在，技術開発研究所絶縁技術グルー プ。主としてガス絶縁開閉器の絶縁に関する研究 に従事。 